\title{
Enhancing communication across a library system
}

ibrarians understand that the complex information environment frequently requires us to both consult with local colleagues and physically assist our patrons with navigating our vast library systems, facilities, and collections. Seeking to enhance customer service and internal library communication, Ohio State University (OSU) Libraries submitted a successful LSTA Innovative Technology Grant Proposal to the State Library of Ohio in 2008. The funding allowed the libraries to purchase Vocera, a wearable hands-free communication system with a proven history of improving the communication and efficiency of

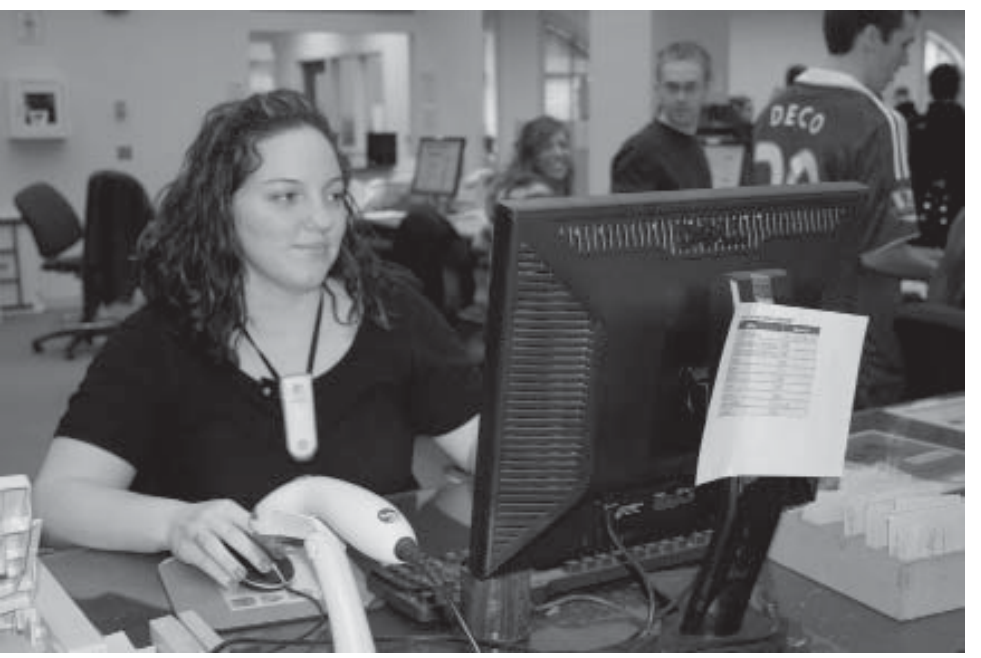

Vocera in use at the Science and Engineering Library Circulation Desk. of individuals on duty for the reference desk or other library functions. Badge users simply press their talk button; say the name of the individual, job function, or group with whom he or she would like to speak; and start talking. Further, Vocera can be used to appropriately match the supply of personnel with patron demand for specific library services. Rather than staffing a service point with multiple personnel just in case a queue might form, one employee can use Vocera to broadcast a message to the group assigned to the service point, asking them to return when needed.

$\mathrm{V}$ o c e r a also interfaces with an organization's telephone network, enabling badge users to make and receive internal and external telephone calls. Thus, if a badge user must consult a library colleague at another institution to resolve a patron's question, he or she can command Vocera to "Dial an outside number" and speak the phone number of the individual. Further, frequently dialed phone numbers can be programmed into Vocera's address book,

Sarah Anne Murphy is coordinator of research and reference at Ohio State University Libraries, e-mail: murphy.465@osu.edu

(c) 2009 Sarah Anne Murphy. This project was funded in part through an Institute of Museum and Library Services LSTA grant awarded by the State Library of Ohio. 
eliminating the need to remember these numbers. For example, the user can press the talk button and command Vocera to "Call police" and immediately speak to a dispatcher. As with a regular phone, badge users can leave messages and place calls on hold. They also have the option to place their badge in "Do Not Disturb" mode when they're in a meeting or taking a restroom break.

\section{Vocera in Ohio State University Libraries}

OSU Libraries serve more than 60,000 undergraduate, graduate and professional students, as well as residents of the State of Ohio. With 22 library facilities distributed over its Columbus campus, the OSU Libraries seek to create a responsive learning environment for all of its constituents. ${ }^{4}$ This can be particularly challenging in a large facility, such as OSU's Science and Engineering Library, with 68,810 assignable square feet distributed over four floors, or the soon to open Thompson Memorial Library with 202,047 assignable square feet distributed over 12 floors. Vocera offers the OSU Libraries the opportunity to re-engineer and transform the traditional library service point. Large reference desks, for instance, can be replaced with a number of smaller service points as librarians and staff may no longer be tied to a desk with the Vocera communications badge. Instead, they can meet and greet patrons at the door and direct them to the service point that will best meet their need. ${ }^{2,5}$ They can also notify a service point in advance that a patron is en route, so that the service point can both look for the patron and start addressing the patron's question.

As conceived, the main mission of the OSU Libraries Vocera project is to enhance customer service, internal library communication, and public safety within the OSU Libraries buildings. Originally, the project plan called for piloting the technology in the Sullivant and Science and Engineering Libraries in winter 2008 , since these libraries accommodated the largest number of patrons on campus. After a three-month project delay, and the realization that additional wireless access points needed to be acquired and installed for Vocera to function in the Sullivant Library, we decided to focus our energies on implementing Vocera in the Science and Engineering Library first. We decided not to place the technology in the Sullivant Library, which would be closing in August 2009 with the opening of the Thompson Memorial Library. We would deploy Vocera in the Thompson library facility.

\section{Vocera goes live in the Science and Engineering Library}

Following a heroic effort of OSU Office of Information Technology personnel and the OSU Libraries IT department, Vocera went live in the Science and Engineering Library on March 26, 2009. Librarians and staff were simultaneously trained to use the Vocera communications badge and software on the "Go Live" date. Additional training sessions for second and third shift staff and student employees were held on April 20 and 21, 2009. Librarians and staff are currently using Vocera to contact one another. They're also discovering ways to use the technology to efficiently and effectively use staff resources.

\section{Project evaluation}

All LSTA-funded projects are required to list measurable project objectives and provide a project evaluation plan. We decided to use Design for Six Sigma (DFSS) principles and associated quality management tools to conceptualize this project and establish the project objectives, outcomes, and evaluation plan. ${ }^{6,7}$ Project objectives include:

- provide "point of need" service to satisfy patron's active learning needs at the time and place of their need;

- improve reference and circulation staff efficiency by $25 \%$;

- recognize cost savings of 20\% for internal library communication; and

- improve referral accuracy by 50\%.

To provide "point of need" service to satisfy patron's active learning needs and improve referral accuracy by $50 \%$, OSU Libraries will use Vocera to begin adapting a proactive rather than reactive customer service model 
to all library service and programs. To benchmark the OSU Libraries' current success with satisfying patron's active learning needs and the time it takes a patron to locate assistance, patron surveys, such as LibQual and WOREP, mystery shopping, and value-stream mapping techniques have either been completed or are in progress. Value-stream mapping, in particular, offers the opportunity to reduce the number of nonvalue-added steps required to provide patrons with "point of need service."

For improving reference and circulation staff efficiency, it was noted that one study of Vocera deployed in a hospital setting revealed time savings of 3,400 hours a year, or the equivalent of 1.7 FTEs. ${ }^{8}$ Such savings may be realized in the Thompson Memorial and Science and Engineering Libraries, enabling administrators

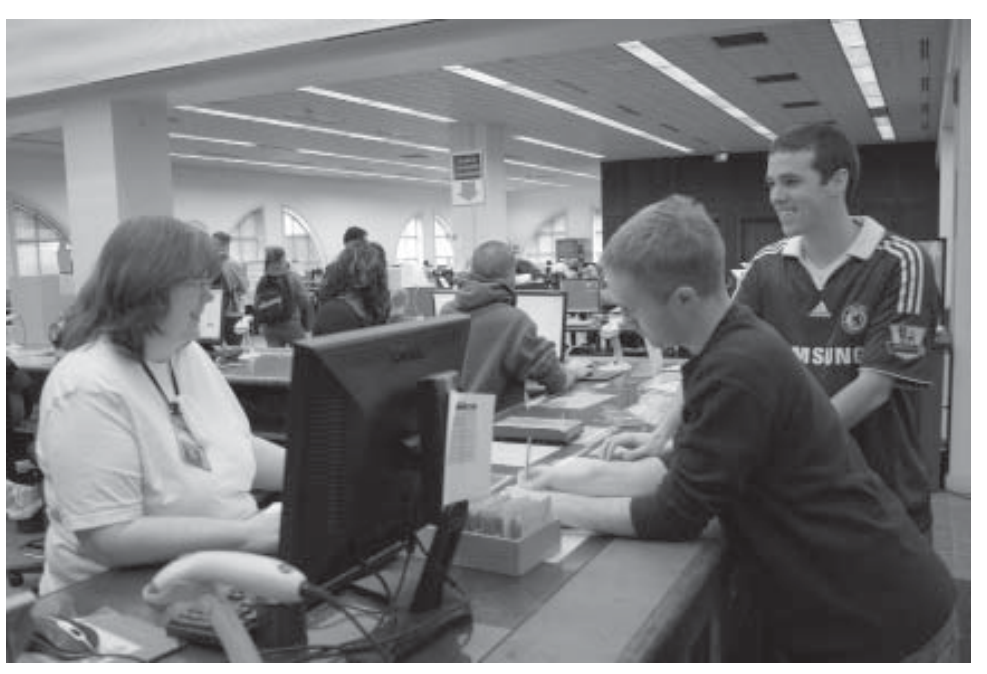

Working with patrons at the Science and Engineering Library circulation desk. Note the staff member is wearing Vocera on her lanyard.

to redeploy staff to other critical functions. Current time and motion studies conducted in the Science and Engineering Library in November 2008 and January 2009 indicate that it takes an average of one minute for a patron to be served and complete a transaction at the circulation desk. Each 15 minutes the desk is open it is staffed by an average of 2.6 employees and an average of 4.1 transactions occur. Patrons asking reference questions at the circulation desk also must wait from 30 seconds to 3 minutes to either be escorted to librarians' offices or for librarians to meet them at the circulation desk to answer their question. By transitioning from a just-in-case to a justin-time staffing model using Vocera, staff can be recalled in real time from other locations within the building to address fluctuations in patron demand, freeing them to address other service needs and projects. Follow-up time and motion studies will be conducted in fall 2009 to determine whether the implementation of Vocera improved reference and circulation staff efficiency.

Lastly, OSU Libraries are currently reliant on desk phones and walkie-talkies for internal voice communication. To determine whether cost savings will be realized with the implementation of Vocera, the November 2008, January 2009, and February 2009 phone bills were reviewed for the entire OSU Libraries system to identify redundancies and opportunities to use Vocera. One limitation of the current OSU Libraries phone bills is that only the number of external local and long-distance calls made are shown, along with the duration of each call. No data is available to indicate the number of internal calls made and the time spent handling these calls. With Vocera, the libraries will have the opportunity to understand both internal and external call volume, and many other relevant outputs. ${ }^{9}$ The OSU Libraries also decided to implement call center technology in August 2009. This project will complement the Vocera deployment. By centralizing incoming calls, and distributing them either via Vocera or the local phone network, additional cost savings should be realized. On completion of the pilot, project phone bills will be reviewed once again, as well as deployment of FTE personnel, and reports generated by Vocera and the libraries call center software to determine the actual total cost savings realized by the project.

The project team chose to express project outcomes in terms of knowledge, affect, skills, and attitudes. Specifically, at the end of the 
project OSU library patrons should be able to locate and engage library employees to satisfy their active learning needs at the time of need (skill). As already noted, this will require OSU Libraries and staff to adopt a proactive customer service model. OSU librarians and staff should be able to:

- locate and engage library patrons and employees to satisfy patrons' active learning needs at their time and place of need (skill);

- recognize and identify the correct librarian or department to refer patron information needs or requests to (knowledge/attitude/skill); and

- understand and appreciate the benefits and potential of wireless communications technology for improving staff efficiency and customer service, as well as managing library costs (knowledge/affect).

Changes in patron behavior, skills, and attitudes will be measured using the surveys listed above. Changes in librarian and staff knowledge regarding referrals will be monitored using the OSU Libraries ASK Reference Database, an internal product used to collect data on OSU Library transactions. ${ }^{10}$

Six months following the initial deployment, members of the Vocera deployment team will lead a discussion with individuals in the Science and Engineering Library to share assessment of preliminary project results, gather opinions regarding the benefits and detractions of implementing the Vocera system from a staff perspective, identify lessons learned, and, if appropriate, identify opportunities for expanding the Vocera deployment and replicating results throughout the OSU Libraries system.

\section{Future plans}

The OSU Libraries is excited to have this opportunity to experiment with Vocera in effort to improve customer service and transform internal communication throughout our facilities. We are looking forward to exploring the potential of Vocera in our Science and Engineering and soon to open Thompson Memorial Library. We believe our project mission will be fulfilled and look forward to reporting future results.

\section{Notes}

1. Vocera Communication. "Helping Hospitals Save Steps, Save Time, Save Lives." San Jose, CA: Vocera Communications, www. vocera.com/solutions/solutions.aspx (accessed April 16, 2009).

2. Lee, Jodi and Christopher Korenowsky. "Off Your Seat and on Your Feet! Proactive Reference Customer Services." Columbus, $\mathrm{OH}$ : Columbus Metropolitan Library, www.placonference.org/2008 / handouts/1013_177 Korenowsky _Christopher_116074_Mar05_2008_Time _104804AM.pdf (accessed April 16, 2009).

3. Ellen Forsyth, "Fancy Walkie Talkies, Star Trek Communicators Or Roving Reference?" Australian Library Journal 58, no. 1 (2009): 73-84.

4. Joseph J. Branin, "Shaping our Space: Envisioning the New Research Library," Journal of Library Administration 46, no. 2 (2007): 27-53.

5. Kathryn Robinson, "Point-of-Need Customer Service: Mobile Service using Wireless Technology," Journal of Access Services 3, no. 2 (2005): 1-14.

6. Kerri Simon, "DMAIC Versus DMADV," www.isixsigma.com/library/content /c001211a.asp?action=print (accessed April 17, 2009).

7. David Woodford, "Design for Six Sigma-IDOV Methodology," www.isixsigma.com/library/content/c020819a. asp?action=print (accessed April 17, 2009).

8. First Consulting Group, "Vocera Benefits Study at St. Agnes Hospital," San Jose, CA: Vocera Communications, www.vocera.com / solutions/documents/St_Agnes _wp_0108_US.pdf (accessed April 15, 2008).

9. Vocera Communications, "Vocera Report Server." San Jose, CA: Vocera Communications, www.vocera.com/products /documents/voc_report_server_3_09. pdf(accessed April 17, 2009).

10. Ohio State University Libraries, "Ask Database," Columbus, OH: The Ohio State University Libraries, library.osu.edu/ask/ (accessed April 17, 2009). $\approx$ 